\title{
2 Societal security in theory and practice
}

\author{
Mark Rhinard
}

\section{Introduction}

Even before the end of the Cold War, numerous conceptualisations of security emerged to challenge traditional territorial versions of national security, each carrying its own philosophical baggage and reflecting its own set of material interests. Indeed, from the end of the Cold War, the focus of many security scholars narrowed to the concept itself: what is it, who does it, and who benefits and loses from its deployment. It is thus no wonder, to use that hackneyed expression, that 'security is contested' - and rightly so. Whether one is an objectivist, believing security threats are 'out there' and require a particular response toolkit that simply needs to be mobilised, or a subjectivist, believing that security threats are 'what we make of them' and that responses are the result of particular linguistic constructions and takenfor-granted practices, knowing what security is and how it is practiced is a core concern of security studies.

In this context, the increasingly popular - and yes, contested - notion of 'societal security' deserves close scrutiny. There are two variants of this version of security. The first variant emerged in the early 1990s by the Copenhagen School of security studies, which directed attention towards 'the ability of a society to persist in its essential character under changing conditions and possible or actual threats' (Waever, 1993: 23). A second variant emerged in Swedish and Norwegian academia and practice, associated with a set of scholar-practitioners including Bengt Sundelius (2005b, 2006; see also Sundelius \& Daléus, 2004), Jan Hovden (1998), Alyson Bailes (2014), Dan Hamilton (2005) and later, albeit in a more critical fashion, by the work of Didier Bigo (2006) and Peter Burgess (2014). There are overlaps between the two variants of societal security, but their development took place mainly in parallel rather than intertwined or - as might have been predicted with one subsuming the other. Each uses a different ontological and epistemological stance on the study of security. Moreover, the latter version of societal security had considerable crossover appeal: it moved swiftly from academia into practice, became associated with objectivist ontologies of viewing the security landscape, and structured - it is now safe to say - at 
least a generation of policymakers in Europe engaged in the analysis, pursuit, and funding of security. That said, the central argument of this chapter holds that associating the first variant with research and the second variant with practice is overly simplistic and ignores the contribution the latter has made to our scientific understanding of security.

In the light of this book's comparative approach to publicly deployed security and safety concepts in the Nordic region, this chapter explores the concept of societal security, considers its bifurcated development and interconnections, and then narrows its focus to the second variant closely associated with the work of Sundelius, Hovden, Hamilton, and others. In the first section, the chapter argues that the two variants, while borne from the same intellectual seed, each grew along relatively isolated and narrow pathways. One turned to a focus on the security of cultural identities and employed constructivist methods to understand them. The other turned to the security of life-giving functions, using mainly objectivist methods to understand and their protection. In the second section, the chapter examines why the latter version was so successfully taken up by policymakers and research funders in the Nordic region, the European Union (EU), and beyond. In the third section, the chapter considers the strengths and weaknesses of this objectivist, 'life-giving functions' variant. The conclusion offers thoughts on how to address those weaknesses and, for the sake of scientific dialogue, how the two variants might be reconnected in the Nordic region and beyond.

\section{Two societal securities}

\section{Society as identity}

The concept of societal security originated in Barry Buzan's classic People, States and Fear (1983) in which he set the tone of discussion for what security 'is' by attempting to distinguish security, in general, from state security. Traditional theoretical approaches to security focus on the state, defined as a legal and political unit enjoying sovereignty over a defined territory or population. The threat in focus was military-induced violence from other, sovereignty-protecting states. The proper means to protect the state and its circumscribed territory was thus often articulated in terms of military defence, and related concepts included alliance formation, band-wagoning, deterrence, and balance of power.

With the state firmly in focus, the traditional security agenda lost sight of what was inside and beyond states, namely 'society', which Buzan described broadly in terms of social, cultural, and psychological formations inside of the state (see Buzan, 1983: chapter 1). Although this initial definition aimed to shift the concerned referent object away from the state onto communities and culture inside the state, a careful reading of Buzan's original formation shows a close alignment between a state and 'its' society, since the latter was seen as circumscribed by the former. The criticism therein was that societal 
security could be viewed as a simple extension of state security and thus missing the target of its own methodological and theoretical aims (Theiler, 2009). Moreover, this initial work conceptualised 'society' in fairly objectivist ways; it was a 'fact' that could be measured by researchers if only the right indicators are found - a perspective that led to some degree of criticism from critically oriented security scholars (McSweeney, 1996).

In subsequent writings - notably Waever et al.'s Identity, Migration and the New Security Agenda for Europe (1993) - the societal security notion was further developed, partly in response to criticism and partly because it had become so empirically relevant. The Balkans, at the time of their research for the 1993 book, was experiencing ethnic conflict at an extraordinary scale. The desired preservation of certain 'societies' seemed to be at the root of most conflicts (Björkdahl \& Gusic, 2013; Thiel, 2007).

Waever et al. (1993) first and foremost developed Buzan's previous arguments by attempting to break the link between society and the state. The authors sought to develop society as an independent security object (no longer ontologically subordinated to the state) and societal actors as potential security players in their own right. 'Society' became the social unit for analysis, defined as the intersubjectively perceived nation, ethnic group, clan, tribe, or potentially any other form of community that provides a source of identity for its members. This articulation, in turn, signalled another shift in thinking about societal security by placing the spotlight on 'identity'. In 1983, Buzan had left the definition fairly open, but with his collaborators in 1993 it was specified as 'a clustering of institutions combined with a feeling of common identity' (Waever et al., 1993: 21). Put another way:

The key to society is that set of ideas and practices that identify individuals as members of a social group. Society is about identity, about the self-conception of communities and of individuals identifying themselves as members of a community.

(Waever et al. 1993: 24; see also 25)

Later, Waever himself was even more straightforward. For him, societal security is defined as 'the defence of a community against a perceived threat to its identity' (Waever, 2008: 581). The definition of 'society' was thus narrowed to equate with 'identity' - a focus that set the precedent for much subsequent research. As Theiler puts it,

[f]or societal security theorists, what characterizes every identity community is that its members value its preservation as an end in itself rather than just a means to achieve other ends, given that it helps sustain those parts of the self-concept that are socially rooted

(2009: 106; see also Herd \& Löfgren, 2009; Roe, 2016).

What about the ontologically objectivist leanings of Buzan's original perspective on studying societal security? This question was not completely 
addressed in the 1993 work. As McSweeney points out, the authors seem 'to want to have a foot in each camp' (1996: 82). At some points in their discussion, Waever et al. (1993) argue for objectivism, but at other points, a constructivist (even deconstructivist) agenda is argued for. In some respects, the issue was 'settled' later, in 1998. Buzan et al. (1998), in focusing an entire chapter on the 'societal sector', make it clear:

Threats to identity are thus always a question of the construction of something as threatening some 'we' - and often thereby actually contributing to the construction or reproduction of 'us'.

(1998: 120)

To study societal security, then, required not (necessarily) an objectivist perspective but rather an understanding of intersubjective processes amongst communities under examination. The door was thereby opened to constructivist perspectives regarding how identities are born, are moulded, are expressed, and - when undermined - become a security problem.

Societal security thus became synonymous with 'identity security' and opened up the possibility of two different (and ontologically varying) ways of studying it. Objectively, scholars could study the preservation of a society's key features, including language and customs. Subjectively, scholars would explore the endurance of a community (embodied by shared set of meanings and identifications) as a locus of identification for its members.

In subsequent years, the study of societal security largely took this second track, as a cornerstone of the Copenhagen School perspective and against the backdrop of the growth of 'securitization' as a central point of inquiry in Copenhagen School-inspired studies. Indeed, this variant of societal security became closely aligned with securitisation as a focus of study. Securitisation derives from 'speech acts' with a 'specific rhetorical structure' (Buzan et al. 1998: 26). Van Munster writes about its three main components: (a) existential threats to the survival of some kind of referent object, that (b) require exceptional measures to protect the threatened object, which (c) justify and legitimize the breaking free of normal [democratic] procedures' (2005: 3 ). To securitise in the societal security context is thus:

[T]o identify a threat to the social and cultural survival of a community and a strategy to ward off that threat and thereby make society secure again... 'Identity emergencies' generate a corresponding willingness to support extraordinary emergency measures beyond 'normal' politics.

(Theiler, 2009: 107)

As Theiler (2009) shows in a review of research on securitisation in the societal security context, the debate on securitisation - how it happens, what is necessary for it to happen, what is sufficient for it to happen, who is the audience - became the main line of inquiry and exploration on societal security studies. The main empirical focus became the insecurities 
of sub-national 'nations', sometimes within states, sometimes across state borders, and often vying for survival, recognition, and/or autonomy.

In sum, the evolution of the original version of societal security opened up conceptual space for the study of security within (and beyond) state borders and what might be worth protecting. From there, however, research evolved in a very specific way. The meaning of society was narrowed down to identity, to the exclusion other domestic, societal values (such as economic welfare). And the way it should be studied was shifted towards, for the most part, securitisation via constructivist analysis (cf. McSweeney, 1996). Those choices enabled another variant of societal security to emerge and prosper on a different pathway.

\section{Society as life-giving functions}

A different version of societal security emerged in the conceptual space provided by the initial 'society as identity' variant of societal security's focus on referent objects inside the territories of states. Yet it bears more resemblance to the initial 1983 version of societal security than to its subsequent development into a focus on identity using constructivist analysis. In defining societal security, Bailes and Sandö wrote that it concerns 'the protection of society as a whole - with its own complex mechanisms, values and culture as its goal, rather than physical boundaries or, as in "human security", the isolated individual' (2014: 15). Sundelius wrote more specifically that 'it is not the national territory that is primarily at stake, but the ability of the government and civil society to function, the necessity to maintain critical infrastructures, for democratic governance to manifest certain basic values, etc'. (Sundelius, 2006: 26). Hence, this version shared a focus on critical, life-giving functions, alongside societal values and their preservation. A focus on values bears a family resemblance to the earlier version of societal security, although it also shares an affiliation with the concept of crisis as defined by crisis management scholars: a perceived threat to the core values or life-sustaining systems of a society that must be urgently averted or addressed under conditions of deep uncertainty (Rosenthal et al., 1989).

While values figure into the definition, it was the 'life-giving functions' that took analytical priority over time. This was apparent in writings by Hovden in Norway, in which attention was placed on conceptualising security in terms of 'the survival and recovery of vital societal functions' (Hovden, 1998), and in those by Sundelius in Sweden, initially titled 'functional security' (Sundelius, 2005a). The focus turned away from cultural referent objects and more on the kinds of functions that must be preserved (Hamilton et al., 2005). In essence, societal security referred to the ability of a society to function. From here, three corollaries were established, which help to explain the subsequent use - and abuse - of the term.

First, the nature of the threat to life-giving functions was bracketed. The nature of the threat was considered fairly unimportant, and not worth 
analysts' attention in an era when security threats could possibly represent the proverbial 'black swan'. This planted the seed of the all-hazards approach which, as discussed below, won the favour of policymakers. Second, the nature of these functions was deconstructed to reveal their transnational character. Owing to the technological underpinnings of modern societies and flows of people, goods and services in an era of globalisation, states were no longer seen as in control of all the functions that give life to a society. Functions, it was argued, cross borders and are regulated and maintained by various kinds of (a) collective governance systems (Rhinard, 2007) and (b) private actors (Bailes, 2008). The pursuit of societal security, Sundelius pointed out in subsequent research, took place outside the national level but not entirely within the international context, either: the proposed term was 'intermestic' (Sundelius, 2006).

Third, focus was placed on the preservation of the life-giving functions. In other words, the methods, ways, and manners in which those functions were best protected became a focus of much analysis - and the emphasis by practitioners who invoked the term. The Norwegian Parliament's 2001 inquiry into the topic adopted a language best translated as 'societal safety' and defined it in terms of '[s]ociety's ability to maintain critical social functions, to protect the life and health of the citizens, and to meet the citizens' basic requirements in a variety of stress situations' (quoted in Olsen et al., 2007: 71; see also Morsut, this volume).

This version of societal security is linked to several related concepts. The first is 'resilience'. In rhetoric and practice, the two have become closely linked (see Berling and Petersen, this volume). Part of this stems from the policy implications of societal security: since deterring and preventing threats is just one part of security society, and most likely impossible, focus must be placed on preparedness. 'Preparing for the inevitable' becomes a key task of authorities - both public and private - and effort must be made on providing 'bounce back' (or 'bounce forward') capacity in the event of a security threat made manifest. Resilience as a study concept attracted greater attention after the London Transport bombings (2005) and Hurricane Katrina (2010) and thereby followed a slightly different research trajectory than societal security (Boin et al., 2010). Nevertheless, the two are based on a common set of assumption and share a conceptual family resemblance, as seen in Sundelius and Rhinard's work on international cooperation as a source of resilience in the face of transnational threats (2010). The second related concept is 'crisis'. Societal security is in some respects a descendent of the intellectual framework associated with studying 'crisis management' (Rosenthal et al., 2001). In that literature (see Boin et al., 2005), the notion of a crisis was a kind of 'manifested threat': an unexpected event requiring an urgent response under conditions of uncertainty. Societal responses required a full range of capacities ranging from prevention to recovery. Clearly the two were closely linked intellectually and that link became obvious in how societal security was used ('t Hart \& Sundelius, 2013; see also Stiglund, this volume). Bigo et al. even argue 
that these related concepts explain the bifurcation of research on societal security in general. They write that 'Scandinavian actors' have 'contributed to shift the meaning of societal security from the identity of society in a context of migration to the resilience of the society in the context of crisis' (Bigo et al., 2014: 12). The third related concept is 'risk', a phenomenon of interest to both scholars and practitioners ostensibly because of the increasing complexity of modern societies and the challenges of protecting it. Notions of risk and risk management often intermingle with conceptions of societal security, especially when the latter is used to encompass goals that span the civilian/ military divide and which focus on societal vulnerabilities (Petersen, 2012).

This version of societal security was quickly adopted by policymakers. Since the subsequent section explains why this was the case, just a few words are required here to explain how policymakers took up the concept. In Nordic countries, as has been set out in this volume, societal security gained currency as the governing concept for the work of civil security agencies (Larsson, this volume; see also Bigo et al., 2014). Around the year 2000, the Norwegian government adopted samfunnssikkerhet as a doctrinal concept, guiding government policy especially as it was carried out by the Directorate for Civil Protection (Direktoratet for Samfunnssikkerhet og Beredskap, DSB), a Norwegian government agency under the Minister of Justice and the Police (see Morsut, this volume; Burgess \& Mouhleb, 2007; NOU 2000:24). The same holds for Sweden's then-crisis management agency (Swedish Emergency Management Agency (Krisberedskapsmyndigheten, KBM)), which around 2006 began using (alongside other terms) societal security as both an operative concept and one intended to guide research funding agendas. ${ }^{2}$ On the operative side, KBM's succeeding agency, Swedish Civil Contingencies Agency (MSB), used the concept in organising its seven, cross-governmental coordinating networks: each was focused on coordinating responses to preserving a core set of life-giving functions during crisis (transport, energy, communication, etc.). On the research funding side, MSB used the concept to suggest new research themes and it still features prominently to this day (see also Larsson, this volume). The latest MSB research strategy is aptly named 'Research for a Safer Society: New Knowledge for Future Challenges 2014-2018'. The Norwegian Research Council also dedicated significant research funding in 2007 to many projects under the rubric of 'SAMRISK', or 'Societal Security and Safety' research programme, now in its second incarnation. As Bigo et al. put it, 'civil security agencies of Scandinavian countries make up a dynamic environment where societal security can thrive' (Bigo et al., 2014: 13). While Finnish and Danish discourses differed slightly, as shown in this volume, some essential conceptual similarities emerged in those settings too (see also Liebetrau, and Branders and Valtonen, respectively, this volume).

At the Nordic level, the use of societal security has been used to help shape cooperation and guide research agendas. In April 2009, Nordic ministers signed the Haga Declaration intended to boost cooperation on 'societal 
security' issues - mainly defined in terms of civil security questions such as air safety, maritime security, energy security, and terrorism (Bailes \& Sandö, 2014; see also Introduction, this volume). Within this declaration, the concept of Nordic solidarity was used to justify stronger and more indepth cooperation on societal security. Nordic ministers gathered again in 2009 to endorse the 'Stoltenberg Report' on Nordic foreign and security cooperation, which included a set of proposals for greater cooperation across the field of security policy, prominently including 'Samfunnssikkerhet' (Stoltenberg, 2009). The Nordic Council of Ministers also tasked its funding body - NordForsk - to call for more research in the field of societal security. NordForsk initiated several multi-year funding streams, named 'Nordic Research Programme for Societal Security'. Several major centres of excellence and research programs now exist to boost research and tie research findings and policy practitioner needs together. The Nordic Council, comprised of parliamentarians from various Nordic countries, recently praised growing Nordic cooperation on 'societal security' ranging from fires to terrorist attacks. But they chastised Nordic ministers for a lack of systematic follow-through of shared initiatives and called for greater institutionalisation of societal security cooperation (Nordic Council, 2019).

Societal security also gained traction at the international level. The idea of societal security was presented as a useful alternative to the 'homeland security' terminology used in the United States, and played to the strengths of the EU's civilian (what some would call 'softer') capacities related to safety and security. In the post 9/11 world, particularly, the societal security terminology appealed to EU institutions attempting to demonstrate their relevance in an age of non-traditional security threats. It proved useful to practitioners emphasising the importance of 'joining up' the EU institutions' sprawling capacities related to internal security and crisis management (Boin et al., 2007; see also Olsson, 2009). EU officials took up the issue in research funding strategies, too. The rise of societal security as a policyrelevant concept coincided with the EU's adoption of a series of major 'security research programmes' embedded within the Framework Programmes. This took place initially in Framework Programme 6 and then Framework Programme 7 and Horizon 2020, both continuing the trend. In each programme, 'security' featured as a major thematic pillar alongside others such as 'engineering' and 'arts and sciences'. In the Horizon 2020 research program, use of the concept has moved into titular form: a main theme is now called 'Secure Societies' (European Commission, 2014). We might also note the Organisation for Economic Co-operation and Development (OECD), which formed a High Level Risk Forum and developed international standards on the principles on 'the governance of critical risks' - using terminology associated with societal security to explain its 'whole of government approach' (OECD Council, 2014).

The societal security variant described earlier demanded a reconsideration by both practitioners and scholars of the protection of domestic 
populations. As Burgess argues, this variant required scholars to reconsider how changing societies, driven by new technical infrastructures, develop new values in relation (and sometimes opposed) to those infrastructures: 'the concept remains geared towards describing the ability of a society to persist in its basic material infrastructure as well as in its core immaterial values' (2014: 4). For practitioners, the concept draws attention to the fact that mobilising for societal security is a cross-sectoral, cross-border, and multi-level endeavour. In short, societal security offers a way of conceptualising what is happening in today's (post-9/11) security practices and focuses on the mid-level referent object of the core, life-giving functions of society. It encourages research into the sectoral functions of society and how security is being organised to ensure their preservation in light of often unpredictable threats.

Thus, although the first variant of societal security served as a necessary precursor to the second, the two research tracks diverged significantly thereafter. Whereas the former turned sharply towards the study of the intersubjective construction and protection of identity, the latter developed in line with objectivist ontologies focused on inevitable threats 'out there' and the necessary protection of life-sustaining systems. This latter development may not have been the original intention of conceptual innovators like Sundelius, who in other writings maintain the subjective notion of 'threats' and 'crises' (Boin et al., 2005). And scholars like Bigo have recently moved towards a fully constructivist approach to studying this version of societal security. He observes its use by communities of practitioners (rather than what it is or how to achieve it) to understand what actors do in its name, according to particular interests (see Bigo \& Martin-Maze, 2014). But objectivism became ingrained when public policymakers adopted the concept to guide policy reform - and by scholars intent on conducting policy-relevant research that might help to improve 'real life' security.

\section{The policy utility of societal security}

As made clear earlier, one of the distinctive features of the second variant of societal security was its crossover appeal. Practitioners and research funders at multiple levels of governance employed the term as a signalling and cohering device. Societal security signalled a distinctive approach to conceptualising and acting upon security in practical terms. It also offered the promise of a more coherent sounding conceptual framework for what would prove to be a wide array of different security initiatives. More specifically, there were five factors explaining why societal security gained such traction amongst practitioners.

\section{Conceptual appeal}

Societal security took root in a Scandinavian - especially Norwegian and Swedish - context because it was conceptually consistent with 
long-standing norms regarding societal solidarity, generally, and Cold War principles concerning how society and government should prepare and respond to a major conflagration, specifically. On the latter point, Sweden adopted the concept of 'total defence' during the Cold War to illustrate the societal-wide need to contribute to territorial defence, at multiple levels of government and across sectoral agencies (Sundelius, 2005b). Total defence suggested that all of society had rights and responsibilities when it came to defending the territory from invasion. The years following the end of the Cold War revealed a need to update that concept. In effect, a window of opportunity arose to reconceptualise Sweden's guiding defence and security principles, and societal security offered linguistic and conceptual continuity (Bailes, 2014).

Societal security was conceptually appealing because it offered a softer and broader vision of security at a time when concerns were turning beyond territorial defence. 9/11 brought home the point of new forms of security threats and the apparent need for a broad-based societal response. The US presidential administration of George W. Bush invested in the concept of 'homeland security' following 2001, which, following the invasion of Iraq and a series of new laws seen to restrict civil liberties (the 'Patriot Act'), quickly became sullied in the eyes of European observers. Europe needed a similar but different sounding concept to frame its own efforts, and societal security helped to signal a useful distinction from the United States.

The latter point was particularly true in the EU, where practitioners were keen to be seen as doing something in line with US efforts but needed to employ a different rhetoric. As Bailes puts it,

while zeal for "homeland security" can demonstrably lead to curbs on popular rights and freedoms, in societal security the "normal", peaceful functioning of society becomes an end to itself. A societal approach thus includes the fine-tuning of protective measures to avoid damaging the social fabric more than strengthening it.

The concept of societal security also played to the EU's competences, including its wide span of legal competences (all of which could be related to 'security' in some way - including, for instance, pandemic control, transport safety, or import/export regulation), and reflected the EU's selfimpression as a cross-sectoral governance system allowing for a wide societal participation (NGOs, private actors) in the provision of security (Boin \& Rhinard, 2008). The concept also allowed the EU to approach security without arousing national-level sensitivities. In the research area, for instance, using the societal security concept to frame EU research funding agendas allowed the EU to claim many goals, including providing research funding, enhancing economic competitiveness, and building a security industry. 


\section{Post-Westphalian affinities}

Societal security gained traction in a European context because it appealed to commentators and practitioners predisposed to thinking in postWestphalian terms. A key implication of societal security's emphasis on the importance of life-giving systems was that such systems were no longer purely national in origin, scope, or breadth. Transport, communication, and food supply systems crossed national boundaries and thus international cooperation was critical (Rhinard \& Sundelius, 2010). Clearly this argument had resonance for European policymakers who were seeking to emphasise the importance of collective governance in providing security. Similarly, the emphasis of societal security on the broad range of governance tools required to provide security - from investments in flood prevention to food safety regulations to police cooperation - fits well with the EU's policy toolbox (which could be smugly contrasted with the fairly narrow security toolbox of NATO).

For practitioners prone to view governance in post-Westphalian terms, with authority draining from the nation-state towards the supranational, societal security could be seen as part of a natural progression of governance. According to this (partly neo-functionalist) logic, the internal market provided the baseline for cooperation; as integration deepened, a number of negative externalities required responsive action. A single energy market is regulated at the European level, but who is responsible for cross-border breakdowns in the electricity grid? Financial services are similarly governed through European cooperation, but national governments retain control when a major financial crisis strikes. The free movement of people and goods brought considerable benefits but also drawbacks in increased security risks. EU officials keen to point out these seeming anomalies could use the security of individuals and key societal systems to justify new initiatives.

\section{Self interest}

As the earlier discussion suggests, self-interest lurks just below the surface of most explanations for why societal security was so easily adopted by practitioners. There were several ways in which societal security could be used by practitioners to gain personal or professional advantage. One was by policymakers at national levels seeking leverage in their calls for security policy reform. The notion of societal security clearly opened up the sense of responsibility for a wider number of governmental actors. To be more specific, the end of the Cold War ushered in a tremendous tussle between different parts of government seeking control over security policy - once the monopoly of defence ministries. For actors seeking to wrench policy authority away from traditional actors, in addition to those genuinely of the belief that security was an 'all of society' responsibility, the term proved quite useful. The Scandinavian countries - or perhaps more accurately, 
Sweden - were predisposed towards adopting this reasoning partly because of its experience with 'total defence' as discussed earlier. Societal security was discursively linked to this concept as a kind of natural successor to the total defence concept - and its corollary call for reform of the government apparatus.

Much of this self-interest, of course, is concerned with resources. Societal security created space for an increasing number of governmental and non-governmental actors seeking a slice of the security funding pie at a time when resources flows were rampant. For instance, the defence community commercial and public officials - were keen to capture security policy in the post-9/11 era (as they did, to a great extent, in Washington, DC). In security research funding, new opportunities arose to wrest control of research and development away from the historically insulated defence industry. In the EU, defence was a policymaking domain dominated by intergovernmentalism. The opportunity to reframe action in terms of security - not least 'societal security' - afforded new legal and financial opportunities for EU actors.

\section{Proscriptive guidance}

Societal security would appear to provide policy-relevant guidance, through illuminating how the forces of globalisation and regional integration demand a rethink of how security is provided. Drawing on existing literature, policy documents, and the results of high-level discussions in Brussels, Rhinard (2007: 11-12) outlined the various policy relevant, normative implications of societal security:

- Societal security focuses on protecting society's key functions; thus, practitioners should seek to protect sites where critical systems intersect. It would require resources in the design and operation of everyday systems, from food production processes to guarding airport perimeters and monitoring sea-going cargo. It would identify vulnerabilities that hide quietly amongst the technologically complex systems that drive our societies. The goal is to prevent a 'cascading effect', where disturbances in one sector trigger breakdowns in another.

- Societal security must be pursued on a multi-level and international basis. From their 'total defence' experience during the Cold War, the Scandinavians know that most security capacities are found at the local level. Security is as much bottom-up as top-down (a philosophy that fits well with the EU's subsidiarity principle).

- Cooperation in military and civilian security matters becomes critical in a societal security approach, as do close links between the public and private sectors. Societal security emphasises the international sources and effects of major disturbances. Given the massive economic and 
information links between Europe and the United States, for example, transatlantic cooperation would seem to be critical to societal security in an age of globalisation.

- Finally, the societal security approach includes principles of evaluation. Adopting it as a guiding principle for action does not mean that a new sector with new policies has to be created. Instead, this approach encourages all sectors to play their part in protecting citizens and critical systems. Capacity building in such areas as prevention, response, and repair - for both known and unknown hazards - should become part of everyday policy management (in EU parlance, this would amount to 'mainstreaming').

These practical implications of societal security seem plausible in terms of policy advice, but serve to blend and even erase boundaries that traditionally divide different activities and forms of societal steering, including civilian versus military preparations, public versus private responsibility, and external versus internal operations. We return to the negative impact of this 'blending' below.

\section{Entrepreneurialism}

As the literature reminds us, conceptually attractive ideas 'do not float freely' and 'windows of opportunity' do not generate change without entrepreneurial effort (Risse-Kappen, 1994). Here, attention can be placed on the efforts of entrepreneurial actors striving to translate academic ideas into policy change. Bengt Sundelius is one such actor, a 'crossover' academic with strong links to policymakers. As the section 'Two societal securities', above, showed, Sundelius' early writings on functional security provided the conceptual basis for the latter version of societal security. From there, Sundelius occupied a series of positions in government which allowed him to deploy the societal security concept with great effect (see also Larsson, this volume). In policy terms, KBM and its successor, MSB, used the concept to shape its policy activities, with Sundelius employed as 'special scientific advisor', providing the intellectual arguments to both guide policy development and to motivate implementation. In research terms, Sundelius used societal security to shape funding agendas at the Swedish level (as research director for KBM, for instance), the Nordic level (as board member of Nordforsk), and the EU level. Regarding the EU, Sundelius was active, early on, in the research agenda formation process of FP7 (taking an outsized role in the European Security Research Advisory Board (ESRAB)). Namely, it was the conceptual ideas put forward by Sundelius and others in ways that appealed to policymakers' ambitions - including the fleshing out of the societal security concept - that explains much of the take-up of the concept in policy circles. Other actors helped to pave the way for the public take-up of this version of societal security but Sundelius stands out in a Nordic context (see also Larsson, this volume). 


\section{The promises and pitfalls of societal security}

The earlier section hinted at the promises and pitfalls of the second version of societal security discussed in this chapter. Here we speak directly to that question. We are particularly interested in highlighting avenues for progress and warnings for future researchers.

\section{Democracy versus security}

An advantage of societal security, as a concept, is its commodious conception of what security means, who is responsible for providing it, and who is allowed to define its contours. Narrow interests once dominated security policy and succeeded, to a great extent, in building a closed network of vested interests to defend a particular definition of security (the militaryindustrial complex). In many respects the advantage of societal security was to 'democratize' security - it allowed different actors to penetrate closed networks. Those actors included private actors along with NGOs and government actors once excluded from engagement in security policy. And yet this inclusion and commodiousness comes with its share of risks, namely oversecuritisation. In the late 1990s and early 2000s it suddenly became vogue amongst governmental agencies to define 'their' particular issue in security terms: climate change, disaster response, energy provision, transport efficiency, and information technology are just some examples. The goal of these definitional moves, of course, was to gain agenda traction and justify larger budgets, but there were - and continue to be - two downside risks. First, and most relevant from an objectivist perspective, the overstretching of the security concept meant that security meant everything, and therefore meant nothing. The actual practice of keeping societies secure could, one might argue, become distracted by the cacophony of new actors claiming ownership. Second, and more relevant from a subjectivist perspective, oversecuritisation could lead to the increasing shift of public policies off the normal agenda and onto the security agenda - with all the negative aspects that entails according to the Copenhagen and Paris (Bigo, 2016) schools of thought.

There is thus a fine line, one can plainly see from the earlier discussion, of 'democratizing' security versus 'oversecuritizing' society. Most evidence suggests that securitisation of a great swathe of public policymaking has, in fact, not taken place (Huysmans, 2011). The extraordinary security agenda has not welcomed on board many new issues; what may in fact have taken place is the securitisation of the normal public policymaking agenda instead (for more on this, see Boswell, 2007 and Rhinard, 2019'). The conclusion to this chapter revisits this question and offers suggestions for further research.

\section{State versus society}

The objectivist version of societal security achieved what the subjectivist version initially could not: to break the conceptual relationship between 
the state and security. As discussed earlier, the initial version of societal security opened the black box of territorial security to see other referent objects - namely national identities - rather than the state itself. However, in preserving the state as an analytical concept whilst looking inside it, early versions in fact reified the state. The objectivist version of societal security explicitly focused on critical, life-giving systems which, although partially located within states, are by their modern nature transboundary. This definitional detail directed our attention immediately outside of the state. However, this promising dimension carries some caveats. For instance, in shifting attention from the state, the concept refocused attention to collective governance - much of which is state dominated (Sperling \& Webber, 2016). Moreover, the policy implications of societal security, as discussed earlier, tended to speak to governmental authorities in terms of implementation responsibility. Thus, states remain strong actors in the conceptualisation of security, even if the importance of the state is usefully diluted in the objectivist approach to understanding societal security.

\section{Intellectual linkages}

The objectivist version of societal security clearly overlaps, often in intriguing ways, with a number of other concepts. One is 'crisis', a term that is, as discussed earlier, dear to the crisis management theory community. For most scholars in that community, a crisis is important in as much as it sheds light on a society's ability to withstand a handful of generic management challenges: detection, sense-making, meaning-making, decision-making, and recovery. As explained earlier, the source of the crisis is less interesting (intellectually speaking) than the effects of the crisis. In this regard, societal security and crisis management both focus on the likely effects of a crisis or manifest threat to security objects within a society; namely, values, democratic institutions, and other fundamental societal features. Indeed, through a variety of research-driven initiatives undertaken in EU policy circles, the concept of 'crisis' has gained a foothold as a close relative of societal security. This is evident in a number of Horizon 2020 calls for research funding, in which effective crisis management is closely linked to the notion of 'secure societies'. And more broadly speaking, crisis terminology has been adopted across an increasing range of policy measures, from health to critical infrastructure protection, and from transport to regional policy (Boin et al., 2013), with arguably dubious effects (Bigo \& Martin-Maze, 2014). The 'crisisification' of European cooperation demands decision-making modes and coordination routines which are largely foreign to traditional EU policymaking. The results can be insulated policy decisions that do not have a wide political backing and which stretch the boundaries of solidarity (Rhinard, 2019).

Another related concept is 'resilience'. In some respects, 'the idea of resilience...was already encapsulated in the academic conceptualization of societal security' (Bigo et al., 2014: 8). In reality, resilience is a closer descendent 
of crisis management, in the sense that the latter created the intellectual possibility that not all threats can be prevented. As such, preparatory action must be taken in order for society 'to withstand, recover from, and mitigate for the impacts of extreme natural and human-induced hazards' (Coaffee, 2013: 326). Resilience has become a popular term amongst practitioners as well as scholars and has spawned a cottage industry of specialised research (Boin et al., 2010). The obvious danger is a tendency to extend securityoriented thinking into ever-further areas of normal public policymaking, as securitisation theorists would warn against. Resilience becomes a subtle security tactic which draws on the 'inevitability' of an attack or an accident and 'designs in' security mechanisms in everything from organisational structures to urban landscape design.

Another concept related to societal security stems from an approach often used to study it: organisational theory. Especially as counselled by Sundelius, societal security is usefully studied in terms of "how to organize for societal security' (Boin et al., 2007). Organisational studies, associated with the fields of public administration and/or business management, examine the norms, rules, actors, and 'cultures' within organisations and, for those interested in more functional-objectivist approaches, how well the organisation handles a variety of challenges from coordination to decision-making to preserving legitimacy. From these perspectives, it is a short step towards the concern for 'good governance'. Sundelius has written that good crisis management is a form of good governance (Lindberg \& Sundelius, 2012) although this connection has not been systematically explored.

\section{Conclusion}

The two versions of societal security used in academic analysis agree on a basic principle - an analytical focus on societies rather than territories but diverge beyond that agreement. One turned to inductive, subjectivist oriented studies of identities as a key referent object. The other turned to more positivist, objective oriented analysis of society preservation as symbolised by life-giving systems as the referent object. The latter through its conceptual appeal, proscriptive character, and entrepreneurship from public academics gained traction in policy circles and has shaped a generation of policymakers and research funders. It would be a mistake, however, to suggest that the former societal security is an 'academic' concept while the latter is a 'practitioner' concept. Both have inspired a host of scientifically robust analyses that have made an impact on security studies scholarship.

That said, more research is needed to further develop the objectivistoriented version of societal security and to avoid some of the pitfalls described earlier. One pressing need is to explore the securitisation effects of the widespread use of 'societal security'. As clearly demonstrated by the socio-historical perspective taken in this volume, research on securitisation has moved beyond the focus on a particular 'speech act' as a sign of 
securitisation (Bigo, 2006; Huysmans, 2011). Studies now include the role of the audience in accepting or rejecting a securitisation effort, and it is increasingly looking at cases of desecuritisation: the depolitisation of security questions into 'normal' public policy question (Balzacq, 2016; Boswell, 2007). Further work should continue in the critical security studies vein partly demonstrated in this volume (see Larsson, and Stiglund, respectively, this volume).

Similarly, synergies between the two societal security approaches could be found by probing the question of securitisation versus desecuritisation. The objectivist version of societal security reveals, through its empirical acuity, the many different parts of society in which security aims, rhetoric, and orientations have taken root. At the same time, it is clear that some parts of society and public policy, including those that were clear candidates for securitisation, have, in fact, not been securitised in the traditional sense (the lack of traction of European 'homeland security' after 9/11 is one example; the 'normalization' of health security is another, arguably). These questions can be usefully explored by twinning the two variants of societal security and asking some new questions: has the use of societal security in practice led to a type of desecuritisation, i.e. a return of current security issues to 'normal' politics? Can this be explained by the EU's traditional role in merging a nation's foreign/security policy into an extended form of domestic policies? In a comparative fashion, can we see the EU's use of societal security as opposed to the use of homeland security in the United States, in which a wide swath of normal policymaking appears to have become securitised? This relates to the earlier discussion regarding securitisation versus democracy: the fact that a great many interests and voices (including critical voices) are engaged in societal security in Europe, across sectors and governance levels, may very well have a positive effect. But this hypothesised effect requires closer analysis.

The two variants of societal security may come together in another sense, considering recent geopolitical developments since 2014. As discussed earlier, the original 'identity' version of societal security was borne out of the tragic examples of the Second World War and the Balkans ethnic conflicts, when armed conflicts emerged from cultural discrimination and identity insecurity. The 'return of geopolitics' (Mead, 2014), symbolised but not limited to the Russian invasion of Crimea, sabre-rattling in the South China Sea, violent conflict in North Africa and the Middle East, and disinformation campaigns and election meddling, reminds us of the persistence of cultural conflicts and identity politics as unfortunate features of our modern security landscape. As the relevance of the Copenhagen School's version of societal security regains prominence and utility, may the opposite become true of the functionalist, 'objectivist' version? The chapters of this book suggest a growing trend in the Nordic region, by which traditional security concepts rooted in territorial integrity and military threats are on the rebound in policy circles. It remains to be seen whether a societal security concept 
emphasising civilian responses to a broad range of threats and risks from across government will prove its relevance or obsolesce in the years ahead.

\section{Notes}

1 That is not to say threats were not discussed. A general overview usually accompanied most societal security studies, and examples were provided: 'nebulous terror networks, unpredictable flu outbreaks and rapidly escalating infrastructure failures. These threats know no borders and deterrence is not always possible' (Rhinard, 2007a).

2 KBM was reformed, and combined with two other agencies, in 2008, as the 'Myndigheten för samhällsskydd och beredskap (MSB)', or in English, the Swedish Civil Contingencies Agency.

\section{References}

't Hart, P., \& Sundelius, B. (2013). Crisis Management Revisited: A New Agenda for Research, Training and Capacity Building within Europe. Cooperation and Conflict, 48(3), 444-461. doi:10.1177/0010836713485711

Bailes, A. J. K. (2008). What Role for the Private Sector in 'Societal Security?' (EPC Issue Paper No. 56). Brussels.

Bailes, A. J. K. (2014). Societal Security and Small States. In C. Archer, A. J. K. Bailes, \& A. Wivel (Eds.), Small States and International Security (pp. 66-79). London: Routledge.

Bailes, A. J. K., \& Sandö, C. (2014). Nordic Cooperation on Civil Security: The "Haga" Process 2009-2014. Stockholm: Report of the Swedish Defence Research Agency (FOI).

Balzacq, T. (2016). Securitisation: Understanding the Analytics of Government. In R. Bossong \& M. Rhinard (Eds.), Theorising Internal Security in the European Union (pp. 45-63). Oxford: Oxford University Press.

Bigo, D. (2006). Protection: Security, Territory, and Population. In J. Huysmans, A. Dobson, \& R. Prokhovnik (Eds.), The Politics of Protection: Sites of Insecurity and Political Agency. London: Routledge.

Bigo, D. (2016). International Political Sociology: Internal Security as Transnational Power Fields. In R. Bossong \& M. Rhinard (Eds.), Theorizing Internal Security Cooperation in the European Union. Oxford: Oxford University Press.

Bigo, D., \& Martin-Maze, M. (2014). D4.1 Report on Theory and Methodology for Mapping of Societal Security Networks. Source: Societal Security Network.

Bigo, D., Martin-Maze, M., Aradau, C., \& Jabri, V. (2014). D4.1 Report on Theory and Methodology for Mapping of Societal Security Networks. SOURCE: Societal Security Network.

Björkdahl, A., \& Gusic, I. (2013). The Divided City - A Space for Frictional Peacebuilding. Peacebuilding, 1(3), 317-333. doi:10.1080/21647259.2013.813172

Boin, A., Comfort, L., \& Demchak, C. (2010). Designing Resilience for Extreme Events (A. Boin, L. Comfort, \& C. Demchak, Eds.). Pittsburgh: Pittsburgh University Press.

Boin, A., Ekengren, M., Missiroli, A., Rhinard, M., \& Sundelius, B. (2007). Building Societal Security in Europe (No. 27) (A. Boin, M. Ekengren, A. Missiroli, M. Rhinard, \& B. Sundelius, Eds.). EPC Working Papers. Brussels. 
Boin, A., \& Rhinard, M. (2008). Managing Transboundary Crises: What Role for the European Union? International Studies Review, 10(1), 1-26. doi:10.1111/j.1468-2486.2008.00745.x

Boin, R. A., 't Hart, P., Stern, E. K., \& Sundelius, B. (2005). The Politics of Crisis Management: Understanding Public Leadership When It Matters Most. Cambridge: Cambridge University Press.

Boin, A., Ekengren, M., \& Rhinard, M. (2013). The European Union as Crisis Manager: Problems and Prospects. Cambridge: Cambridge University Press.

Boswell, C. (2007). Migration Control in Europe after 9/11: Explaining the Absence of Securitization. JCMS: Journal of Common Market Studies, 45(3), 589-610. doi:10.1111/j.1468-5965.2007.00722.x

Burgess, J. P. (2014). The Future of Security Research in the Social Sciences and Humanities. Strasbourg: European Science Foundation, Discussion Paper.

Burgess, J. P., \& Mouhleb, N. (2007). Societal Security: Definitions and Scope for the Norwegian Setting. Policy Brief 2007(2). Oslo: PRIO.

Buzan, B. (1983). People, States and Fear: The National Security Problem in International Relations. Brighton: Harvester Wheatsheaf.

Buzan, B., Waever, O., \& Wilde, J. de. (1998). Security: A New Framework for Analysis. Boulder, CO: Lynne Rienner.

European Commission. (2014). Secure Societies - Protecting Freedom and Security of Europe and Its Citizens. Horizon 2020 Work Programme 2014-2015.

Hamilton, D. S. (2005). Societal Security and Homeland Security. In D. S. Hamilton, B. Sundelius, \& J. Grönvall (Eds.), Protecting the Homeland: European Approaches to Societal Security - Implications for the United States. Washington, DC: The Transatlantic Center of Johns Hopkins University.

Hamilton, D., Sundelius, B., \& Grönvall, J. (2005). Protecting the Homeland: European Approaches to Societal Security - Implications for the United States. Washington, DC: Johns Hopkins University/Center for Transatlantic Relations.

Herd, G. P., \& Löfgren, J. (2009). "Societal Security", the Baltic States and EU Integration. Cooperation and Conflict, 36(3), 273-296. doi:10.1177/00108360121962425

Hovden, J. (1998). Sikkerhetsforskning: en utredning for Norges forskningsråd. Trondheim: NTNU.

Huysmans, J. (2011). What's in an Act? On Security Speech Acts and Little Security Nothings. Security Dialogue, 42(4-5), 371-383. doi:10.1177/0967010611418713

Lindberg, H., \& Sundelius, B. (2012). Whole-of-Society Disaster Resilience: The Swedish way. In D. Kamien (Ed.), McGraw-Hill Homeland Security Handbook (pp. 1295-1320). New York: McGraw-Hill.

McSweeney, B. (1996). Identity and Security: Buzan and the Copenhagen school. Review of International Studies, 22(01), 81. doi:10.1017/S0260210500118467

Mead, W. R. (2014). The Return of Geopolitics: The Revenge of the Revisionist Powers. Foreign Affairs, 93(3), 65-78.

Nordic Council. (2019). Nordic Council Strategy on Societal Security: Adopted at the Session of the Nordic Council, Stockholm, 30 October.

NOU 2000:24. (2000). Et sårbart samfunn: Utfordringer for sikkerhets-og beredskapsarbeidet i samfunnet. Oslo: Justis-og politidepartementet.

OECD Council. (2014). Recommendation of the Council on the Governance of Critical Risks. Paris: OECD. 
Olsen, O. E., Kruke, B. I., \& Hovden, J. (2007). Societal Safety: Concept, Borders and Dilemmas. Journal of Contingencies and Crisis Management, 15(2), 69-79. doi:10.1111/j.1468-5973.2007.00509.x

Olsson, S. (2009). Crisis Management in the European Union: Cooperation in the Face of Emergencies (S. Olsson, Ed.). Dordrecht: Springer.

Petersen, K. L. (2012). Risk Analysis: A Field within Security Studies? European Journal of International Relations, 18(4), 693-717. doi:10.1177/1354066111409770

Rhinard, M. (2007). Societal Security: An Emerging Role for the European Union. In R. Arjen Boin, M. Ekengren, A. Missiroli, M. Rhinard, \& B. Sundelius (Eds.), Building Societal Security in Europe: the EU's Role in Managing Emergencies (pp. 8-21). Brussels: European Policy Centre, Working Paper No. 27.

Rhinard, M., \& Sundelius, B. (2010). The Limits of Self-Reliance: International Cooperation as a Source of Resilience. In L. Comfort, A. Boin, \& C. Demchak (Eds.), Designing Resilience. Pittsburgh, PA: Pittsburgh University Press.

Rhinard, M. (2019). The Crisisification of Policy-Making in the European Union. JCMS: Journal of Common Market Studies, 57(3), 616-633.

Risse-Kappen, T. (1994). Ideas Do Not Float Freely: Transnational Coalitions, Domestic Structures, and the End of the Cold War. International Organization, 48(2), $185-214$.

Roe, P. (2016). Societal Security. In A. Collins (Ed.), Contemporary Security Studies (pp. 215-228). Oxford: Oxford University Press.

Rosenthal, U., Boin, R. A., \& Comfort, L. K. (2001). Managing Crises: Threats, Dilemmas, Opportunities. Springfield: Charles C. Thomas.

Rosenthal, U., Charles, M. T., \& 't Hart, P. (1989). Coping with Crises: The Management of Disasters, Riots and Terrorism. Springfield: Charles C. Thomas.

Sperling, J., \& Webber, M. (2016). Securitization in Large Numbers: NATO and the Ukraine Crisis. European Journal of International Security, 2(1), 19-46.

Stoltenberg, T. (2009). Nordic Cooperation on Foreign and Security Policy. Proposals Presented to the Extraordinary Meeting of Nordic Foreign Ministers in Oslo, 9 February.

Sundelius, B. (2005a). Disruptions: Functional Security for the EU. In A. Missiroli (Ed.), Disasters, Diseases, Disruptions: A New D-Drive for the European Union (pp. 67-84). Paris: Institute for Security Studies, European Union. Chaillot Paper No. 83.

Sundelius, B. (2005b). From National Total Defense to Embedded Societal Security. In Dan Hamilton, B. Sundelius, \& J. Grönvall (Eds.), Protecting the Homeland: European Approaches to Societal Security - Implications for the United States (pp. 1-16). Washington, DC: The Centre for Transatlantic Relations at Johns Hopkins University.

Sundelius, B. (2006). A Brief on Embedded Societal Security. Information and Security, 17, 23-37.

Sundelius, B., \& Daléus, P. (2004). Från territorialförsvar i krig till samhällssäkerhet i fred. Stockholm: Swedish National Defence College, Acta B32.

Theiler, T. (2009). Societal Security. In M. Dunn Cavelty \& V. Mauer (Eds.), The Routledge Handbook of Security Studies. London: Routledge.

Thiel, M. (2007). Identity, Societal Security and Regional Integration in Europe. Jean Monnet/Robert Schuman Paper Series, 7(6), 305-284. 


\section{Mark Rhinard}

Van Munster, R. (2005). Logics of Security: The Copenhagen School, Risk Management and the War on Terror. Odense: Syddansk Universitet Political Science Publications, No. 10.

Waever, O. (1993). Societal Security: The Concept. In O. Waever, B. Buzan, M. Kelstrup, \& P. Lemaitre (Eds.), Identity, Migration, and the New Security Order in Europe (pp. 17-40). London: Pinter.

Waever, O. (2008). The Changing Agenda of Societal Security. In H. G. Brauch, U. Spring Oswald, C. M. Liotta, J. Grin, \& P. D. N. B. B. C. P. Kameri-Mbote; (Eds.), Globalization and Environmental Challenges (pp. 581-593). Berlin, Heidelberg: Springer. doi:10.1007/978-3-540-75977-5_44

Waever, O., Buzan, B., Kelstrup, M., \& Lemaitre, P. (1993). Identity, Migration, and the New Security Order in Europe. London: Pinter. 